\title{
Brand Strategy and Brand Evolution: Welcome to the World of the Meme
}

\begin{abstract}
This paper explores the idea of the meme as it relates to branding. In evolutionary theory the meme is the cultural equivalent of the gene. Memes are seen as self replicating entities which jump from human host to human host. In a similar way to the gene in the biological world, there is a complex changing business environment where some memes are successful and others are not. This paper argues that brands are meme like entities, conforming to the dictates of evolutionary theory. Considerable existing research in branding argues that success results from the increasing complexity of brand management and strategy. The memetic approach provides a different perspective on brand success however. Memetics does not argue for sophistication and complexity as a route to success. Natural selection is based purely on the fitness of the meme. The ability of the latter to survive is depended on its fitness of reproduction in a hostile environment. This theory and its research applicability to branding is explored. Finally, another property of evolution, the concept of mutation, is also briefly examined. It is argued here that brand mutations can have both positive and negative impact on brand building. Consumers, as the hosts of brand memes, could play a vital part in the reproduction process where error copying occurs.
\end{abstract}

Key words: brand, evolution, meme, natural selection 


\section{INTRDUCTION: ON MEMES, BRANDS AND BRAND EVOLUTION}

It is well documented that marketers will often borrow ideas from other disciplines (see Arndt 1984). One area that with rich potential for application is in the area of evolutionary theory (Dawkins 1976). The latter's book put forward the idea that genes are replicators existing in a competitive drive for biological evolution. Dawkins also pointed out that there is also another replicator which exists within culture and that is the meme. The latter propagates by jumping from brain to brain, literally infecting the host. The basic idea as Blackmore (2000) points out is very simple. Everything that we have learned from someone else is a meme, including songs, rules, stories and by implication, brands. This paper seeks to explore the relationship between notions of evolution, memes and brands. It is suggested that this is an important area largely neglected by academic research into marketing and that a significant potential for further research exists. This conceptual paper begins by reviewing some standard interpretations of the notion of branding and then proceeds to examine brands and meme theory. In particular the issue of how brand evolve over time is addressed.

Brands are one of the most valuable assets for many organisations. They have been researched from many different stakeholders' perspectives, including brand owner's and consumer's perspectives. According to the American Marketing Association (AMA), a brand is a name, term, sign, symbol, or design, or a combination of them all, intended to identify the goods or services of one seller or group of sellers. The aim is to differentiate them from those of competitors (AMA, 1960). Realising the importance of intangible associations, Bennett (1988) proposes a slightly modified definition, pointing out that a brand is more than just a name, a term, or a symbol. It is any other feature that identifies one seller's good or service as distinct from those of other sellers. Wood (2000) claims the key words 'any other feature' allow intangibles to be included for the purpose of differentiation.

Accepting the brand definition of AMA, Aaker (1993: 15-27) proposes the concept of 'brand equity'. This suggests a set of assets and liabilities, such as loyalty, awareness and other associations. These factors, linked to a brand, could also add or subtract the perceptions of a company's products or services to customers. Aaker (1996:27), claims that today's complex marketing environment, which is the brand building context, includes 'fragmenting markets \& media' and 'complex brand strategies \& relationships' as well as 'proliferation of competitors', thus making it very difficult to build a strong brand. To cope with this increasingly complex environment, companies should adopt the concept of brand identity which helps to establish relationships with customers by generating 'value proposition involving functional, emotional or self-expressive benefits' (Aaker, 1996: 68). A strong brand identity has broad dimensions and perspectives, (Aaker, 1996: 76). These factors can build clear, rich and different brand equities and a firm should consider its brand as not only a product, an organisation, a person, but also as a symbol, all of which include a wide range of tangible and intangible associations. Aaker (1996: 78) points out that not all brand identities need to employ all perspectives however. 
Keller (2003: 38) also considers that brand management may be more difficult than ever as 'a number of recent developments have occurred in recent years which have significantly complicated marketing practices, posing challenges for brand managers. The 'savvy customers', 'more complex brand families and portfolios', 'more sophisticated and increasing competition', 'fragmenting media coverage' among some other effects, have created an ever complex and changing marketing environment where 'customer-based brand equity' will be helpful for marketers trying to cope with the situation (Keller, 2003: 38-43). According to Keller (2003: 75-103), in order to build a strong brand, it is necessary to build a four step 'brand ladder', from identity to meaning, to responses to relationships, in which the complexity and sophistication is accordingly increasing. Therefore, Keller (2003: 100) claims that strong brands thus have both breath (in terms of duality) and depth (in terms of richness) because collectively the various aspects of brand meaning and the resulting responses of consumers produce strong consumer bonds.

There is in existence considerable amounts of other literature indicating that the nature of brands and branding changes over time (Goodyear, 1996; Kapferer, 1997; Young and Rubicam, 1994). McEnally and de Chernatony (1999), suggests that various brand typologies show that strategists have plans for particular brand concepts whose nature is unique to the particular brand concept and over time. Brand concepts have ranged from the brand acting as a simple identification device to the development of complex, value-laden identities. Goodyear (1996) proposed a model to show how the nature of branding has evolved over time. It is argued that brands tend to go through a six-stage process, which includes: Stage 1: Unbranded Goods - Stage 2: Brand as reference - Stage 3: Brand as personality - Stage 4: Brand as icon - Stage 5: Brand as company - Stage 6: Brand as policy.

Although branding may not reach all six stages in all product categories, the argument is that the complexity of brands increases over time, due to competitive pressures, the sophistication of management and especially because of the demands of the consumer (McEnally and de Chernatony, 1999). De Chernatony and McDonald (2003: 49) reiterate that the brands of companies should grow into their role of projecting a particular personality under more intensive competition. From this outline of the literature, it seems many marketing practitioners and researchers incline towards the point of view that it is an inevitable tendency that the nature of brand and brand management are evolving in the direction of high complexity and sophistication. This is seen as a necessary precondition of being able to cope with the ever changing and challenging marketing environment. Particularly, intangible associations play an increasingly important role in the brand equity building process. For Aaker and Joachimsthaler (2000), brands also become increasingly complex over time. For them, the process starts from the building of an identity, moving through to the development of relationships with customers, to the development of complex systems of brand architecture. What appears to be the case from the literature is that relationship building between brands and customers is becoming the primary objective of brand management, where high degrees of complexity and sophistication exist.

\section{BIOLOGICAL EVOLUTION AND THE MEME}


It can be postulated that one alterantive way to look at the development of the brand, which strips away notions of complex improvements, is to consider the notion of the meme and its cultural implications for marketing management. Firstly, it is important to examine the notion of evolution. Charles Darwin is the person most strongly identified with the discovery of evolution. In his book: The Origin of Species by Means of Natural Selection (1859), the process of 'natural selection' indicates the members of the population who are most fit, will have the most progeny and will therefore become more prominent in the population in future generations. In modern biology, evolution is considered to be the process by which some of a population's inherited traits become more commonplace, at the expense of others, from generation to generation. This can be measured in terms of the variant genes, known as alleles, which encode competing traits (Stearns and Hoekstra, 2005).

It can be argued that genes and the notion of memes have a direct relationship to brands and brand management. Richard Dawkins, basing his work on Darwinism, coined and defined the idea of the meme as the least unit of cultural transmission, analogous to gene in biology (Dawkins, 1976). It is a replicator, a self-replicating and self-propagating entity whose survival to a large extent depends on its success and advantage in relation to other competing memes. A few examples of memes he suggested are tunes, ideas, catch-phrases, clothes fashions, ways of making pots or of building arches, which can propagate themselves and get passed on by imitation. Dawkins (1976) argues that certain genes succeed because they are successful at producing more identical genes. The same process applies to memes, whose success depends on their ability of producing more identical memes. One issue that needs to be clarified is that the selection happens on the level of the expression of genes, as natural selection is the correlation of traits (expression) with reproductive success (Stearns and Hoekstra, 2005: 2).

In branding, it implies that the memes that eventually dominate will be the ones most likely to reproduce themselves because the trait they express is the most 'fit' for the environment. Importantly, it may not necessarily coincide with the memes that are most successful in terms of creating complexity and sophistication in brands and brand management. Dennett (1995) argues that evolution is inevitable once three conditions are met: heredity, variation and selection. Meme, just like Blackmore (2000) described, perfectly satisfies these three conditions because 'the enormous variety of behaviours in human beings' which are 'copied by other human beings' but clearly, 'not all the copies survive'. Therefore, the brand, as a form of meme-complex which consists of memes, also satisfies the three conditions of evolution. There are enormous numbers of different brands that have been created since the start of human history and not all can possibly survive. One possible explanation for the successful brands is that they possess the winning meme. .

\section{MEMES, BRANDS AND NATURAL SELECTION}

The study of Memetics has been introduced in the business context before. De Jong (1999) concludes that a meme's replication power is in part dependent upon the success and power of 
the actor (person) responsible for replicating the meme. Vos and Kelleher (2001) suggest the mergers and acquisitions can be a dominant choice among strategic thinkers. Frank (1999) finds that the determining variable of the prevailing memes in the financial markets is not the 'good' one, i.e. market efficiency, but other dimensions of fitness (e.g. psychological appeal), which could lead to less efficient financial strategies. Marsden (2002), attempts to reveal the position of 'healthy living' in the consumers' mind, by unpacking the notion into relevant components. It is clear that the notion of 'healthy living' is a meme-complex constructed by the relevant components, albeit the structure of the mechanism underlying is not revealed.

As pointed out earlier, the success of a meme depends on the 'fitness' of its place in the environment, where natural selection is taking place. Because of this, it is essential to understand the different rationales of fitness within various circumstances. Memes are ideas that inhabit the brain, which exert an influence over human beings in a business context. For example, consumers and managers are the mechanisms that carry memes in their brains and spread the memes by various forms of communication. These are the processes, which are deciders of the 'rationales of fitness'. A consumer would define a meme's fitness on the base of its ability to fulfil the need of him or her. The brand that satisfies more customers, will tend to increase its presence in a competitive market, the latter regarded as a meme pool. The need could be value for money, or a sophisticated self-image. A manager would define a meme's fitness on the base of its ability to fulfil the strategic objective of the company. The strategic objective could be larger market share, higher profit margin or bargaining power against suppliers. What follows is an example of memes in action. This is largely anecdotal and it is recognized further systematic research needs to be undertaken in this area.

During the 1970s, Sony developed a machine using Betamax technology to deliver home video-taping equipment. Sony pioneered most of the advancements in the home video industry and most experts agree that the tape quality on Betamax was superior to that of its rival. Until the early 1980s, the word 'Betamax' was used as a synonym for 'video recorder'. This became an important intangible association, which favored the reproduction of Betamax. From 1981 onwards, Betamax-based machines were rapidly losing the popular favor of consumers however. In 1987, VHS had gone way beyond the tipping point, with a $95 \%$ share of the market. Sony lost this battle and the war, regardless of the fact that they enjoyed the first entry advantage and the reputation of superior tape quality. This provides a unique insight into brand competition, by applying a memetic approach to analyse the incident. It becomes clear that the Betamax brand consisted of a range of successful memes until VHS came along.

The brand of VHS consisted of the following memes: firstly, there were a number of companies manufacturing and marketing VHS-based machines via licensing while Sony was reluctant to share their superb technology. In other words, there were a number of companies reproducing the meme of VHS. In comparison, only one company was reproducing the meme of Betamax. Secondly, as an inevitable result of licensing, more video tape rentals of VHS were available than those for Betamax. The higher availability of video tapes for VHS facilitated the reproduction of the VHS meme because the tape and machine symbiose with each other. Thirdly, the VHS machines could record for a considerable length of time while 
Betamax machines could only record for one hour, which is less than a football match or a movie. The implications of this were that Betamax video owners had to swap tapes over during a movie, while retailers had to supply more cassettes. The frustration caused put off the reproduction of the Betamax meme. Fourthly, VHS machines were cheaper than Betamax machines (Haig, 2003: 23-27). This again facilitated the reproduction of the VHS meme. The four memes together construct the mechanism, which increased the reproduction of the VHS meme generally. In the process of evolution, the VHS memes acquired dominance, because they were more 'fit', in the terms of reproducing themselves. The Betamax meme was selected out, regardless its picture quality, and the reputation of Sony. The mechanism of the Betamax meme was certainly not less sophisticated or less complex than VHS meme, but the evolution favored VHS meme, because it was more 'fit' than the Betamax meme in terms of self replication.

Since the 1970s, the retailers' own label brands have been experiencing huge successes against manufacturers' brands. Retailers have launched their own brands through generic ranges of products, as they entail higher profit margins as well as having more bargaining power against suppliers. Good quality at low price certainly is an attractive proposition to consumers, but the advantage of own label brands against other generics is that the retailers provide plenty of shelf space which manufacturers strive for with all sorts of strategies, including spending millions of pounds on advertisements to establish a sophisticated brand image. The own label brand generics have been expanding prolifically in recent years, without spending large amounts on advertising, which was considered by manufacturers as the most efficient way to create wide brand awareness and a sophisticated brand image. The shelf space drastically increases the chance of the own label brands to be consumed by the retailers customers, against the manufacturers' brands. The meme of own label brand survives because the shelf space facilitates the reproduction of the meme. In the terms of brand equity, there are many manufacturers' brands which are very sophisticated, with many tangible and intangible brand associations, but it is unlikely that those sophisticated manufacturers' brands will be able drive out the own label brands from the supermarket shelves. Therefore, it is not necessarily that the brand with most sophisticated brand equity will be the most successful. There is no sign that the sexy and cool Levi Strauss jeans will overrule Asda's George jeans or frozen food specialist Bird's Eye's garden peas cancel Tesco's Value peas.

In biology, natural selection means that differential survival and reproduction of individuals. The latter differ in heritable traits and in responds to selection. Traits that improve reproductive success increase in frequency over time (Stearns and Hoekstra, 2005: 2). In memetics, the memes that have the expression which improve reproductive success are more likely to survive and over time appear to be more successful. As Dawkins (1998: 304) claims, those memes that spread do so because they are good at spreading, they are not necessarily 'good' or 'bad'; they simply spread for the sake of spreading. In the terms of branding, a brand is not just the sum of its brand attributes, but a mechanism that is fit, that is able to be self-replicating. The increasingly complex and competitive marketing environment does not necessarily imply that the brands have to be increasingly sophisticated to survive or succeed. The successful brands are those who have the mechanism to improve reproduction of the 
meme. Therefore, an important part of the argument maintains that brands or brand management does not necessarily evolve in the direction of complexity and sophistication, unless it is obliged to facilitate the reproduction of the brand or brand management meme.

\section{MEMES, BIOLOGY AND BRAND MUTATION}

Consumers are not just the operand resources which are the subjects of marketing activities but the operant resources which can produce effects (Vargo and Lusch, 2004). In the memetic approach, the consumer, as the recipient of brand memes, plays the selection role which decides the success of memes. In this scenario, it is possible for a process of brand mutation to occur, when consumers actively interfere in a negative way with the process of meme reproduction. In biology, mutation is a hereditary change in the DNA sequence or in chromosome number, form, or structure and most of mutations arise because of errors during DNA replication (Stearns and Hoekstra, 2005: 100). Mutation, in biology, can affect the function of individual organisms, both positively and negatively. Some mutation helps to generate antibody diversity in the immune system; in contrast, some mutation could cause cancer. The new technologies, such as the internet and mobile phone technology, facilitate meme reproduction at a much faster pace, compared to the traditional communication through word of mouth or even television. For this reason, theoretically, it is more likely that brand meme could mutate during the process of replicating. A funny picture of a brand sent through emails could generate brand awareness, while a prank video uploaded on YouTube about a brand is very likely to generate error copying during the reproduction process, when internet users perceive the manipulated meme of the brand. In this sense, the brand meme could be changed unexpectedly during the reproduction process. For example, Burberry's tartan baseball hats had been very popular among a certain group of urban youth which regard the tartan baseball hat as an identity of their culture. During the reproduction process, the error copying occurs: Burberry's associations with the Royal family and celebrities shifted the associations to urban and anti-social youth groups. The changed and mutated memes continue to produce more and more memes in and even outside, the original youth group that was implicated. Urban, rebelling and anti-social characteristics can potentially be inherited and then spread through the population. This mutated brand meme has achieved such dominance, that Burberry had to terminate the production of their tartan baseball hats to prevent the meme from spreading to other product categories of the company.

\section{CONCLUSION: MEMES UNDER THE MICROSCOPE}

In developing the theme of this section, some practitioners are trying to take advantage of the replicating process of memes for marketing purposes through the 'viral marketing' concept. Various strategies have been developed to promote the brand through this medium. At the current stage, it has not been widely used because it is not easy to control the whole spreading process. It is argued though, that research on brand mutations will help to explore the area, in order to prevent possible negative impacts on the brand or even to find out how the meme is successfully transmitted. Theoretically, there are many other properties of biological evolution that need to be applied into the brand evolution concept in order to explore the nature of 
brands in the memetic world, while more empirical research on brand meme is needed to test the applicability of the evolutionary theory as applied to branding, especially at the stage where memetics as a theory is still being disputed. As a priority, it is necessary to get the theory more fully investigated and developed.

If we apply the general theory of evolution and if we assume evolution takes place in the branding area, then the following argument exists. The brand is regarded as the unit of selection and it is not necessarily the case that the latter will have to develop from a simply a reference to a sophisticated mechanism. To cope with a changing environment, brand managers routinely develop the sophistication of the brand in order to survive and achieve reproduction success. The significant determinant variable here is the 'fitness' of the brand, i.e. how good the brand meme can reproduce itself to ensure its survival and reproduction. In this context, the notion of 'fitness' is subject to the rationales of different hosts of the brand meme. In an ideal rational world, the fitness of brand meme to the consumers is to satisfy their needs, which could be tangible and or emotional. The fitness of brand meme to the marketers is the satisfying of their strategic objectives, including larger market share, returns on investment and higher profit margins for example.

It would appear that generally speaking, researchers in marketing are placing more efforts on an understanding of the emotional attributes of branding. This paper leads to a different research approach however, one that is that quite different from the current trend of research on branding. In today's high technological environment, the transmission and possible mutation of the meme is the key issue to examine. What is needed are ways to map the meme and its onward transmission through consumers. We need to understand and not ignore this cultural domain of evolutionary theory. Its ideas are simple yet powerful, with probably enormous significance for understanding brands and brand management better. If this paper helps to develop a research theme in the area of the study of memes, then it would have achieved its purpose. Before theory can be put into practice, we need to firstly fully understand the theory and the potential of the various research approaches it could engender. This, perhaps the greater challenge here, is the need to research the physical agents of meme in order to understand how the latter are ??? transmitted from host to host. Without this we hare only have partial knowledge of this important area.

\section{REFRENCES}

Aaker, David (1991), Managing Brand Equity: Capitalizing on the Value of a Brand Name, Free Press, New York, NY

Aaker, D (1996), Building Strong Brands, Free Press, New York, NY

Aaker, D and Joachimsthaler, Erich (2000), Brand Leadership, London Free Press

ARNDT (1985) On Making Marketing More Scientific: Role of Orientations, Paradigms Metaphors and Puzzle Solving Journal of Marketing, Vol. 49 (summer) pg. 11-23

Bennett, P.D. (1988), Dictionary of Marketing Terms, The American Marketing Association, Chicago, IL, p. 18. 
Blackmore, Susan (2000) The power of memes, Scientific American, Vol. 283, Issue 4, Page 64-66.

Darwin, C.R. (1859) The Origin of Species. London: John Murray

Dawkins, Richard (1976), The Selfish Gene, (2nd ed'n., 1989), Oxford: Oxford University Press.

Dawkins, Richard (1998), Unweaving the Rainbow, Penguin: London.

De Chernatony, Lesley and McDonald, Malcolm (2003), Creating Powerful Brands, Butterworth-Heinemann, Oxford

De Jong, M. (1999). Survival of the institutionally fittest concepts. Journal of Memetics Evolutionary Models of Information Transmission, Vol. 3, Available at http://jom-emit.cfpm.org/1999/vol3/de_jong_m.html

Dennett, Daniel (1996) Darwin's dangerous idea: evolution and the meanings of life, London: Penguin

Frank, Joshua (1999), Applying memetics to financial markets: Do markets evolve towards efficiency? Journal of Memetics - Evolutionary Models of Information Transmission; Vol. 3, Issue $2, \mathrm{p} 1,15 \mathrm{p}$

Goodyear, Mary (1996), Divided by a common language: diversity and deception in the world of global marketing, Journal of the Market Research Society, 38 (2), 105-122.

Haig, Matt (2003), Brand Failures: the truth about the 100 biggest branding mistakes of all time, U.K.: Kogan Page Limited

Keller, Kevin Lane (2003), Strategic brand management: building, measuring, and managing brand equity, Upper Saddle River, N.J.: Pearson Education

Kapferer, Jean-Noel (1997), Strategic Brand Management: Creating and Sustaining Brand Equity Long Term, Kogan Page, London.

Marsden, Paul (2002), Brand positioning: Meme's the word, Marketing Intelligence \& Planning, Vol. 20, Iss. 4/5; pg. 307-313

McEnally, Martha R. and L. de Chernatony (1999), The evolving nature of branding: consumer and managerial considerations, Academy of Marketing Science Review. Vancouver:Vol. 1999 pg. 1

Stearns, Stephen C. and Hoekstra, Rolf F. (2005), Evolution: an introduction, Oxford: Oxford University Press.

Vargo, Stephen L. and Lusch, Robert F. (2004), Evolving to a new dominant logic for marketing, Journal of Marketing, Vol. 68 Jan. Pg. 1-17.

Vos, Ed and Kelleher, Ben (2001) Mergers and takeovers: a memetic approach, Journal of Memetics - Evolutionary Models of Information Transmission, Vol. 5. Available at http://jom-emit.cfpm.org/2001/vol5/vos_e\&kelleher_b.html

Wood, Lisa (2000), Brands and brand equity: definition and management, Management Decision, London: Vol. 38, Iss. 9; pg. 662

Young \& Rubicam (1994), Brand Asset Valuator, London: Young \& Rubicam 